\title{
Analysis about Risk Changes before and After Inspection of 23 Storage Tanks and Research on the Inspection Strategy
}

\author{
Fang Zhou ${ }^{\mathrm{a}}$, Xing Shu ${ }^{\mathrm{b}}$, Chen $\mathrm{Qi}^{\mathrm{c}}$, Shen Gongtian ${ }^{\mathrm{d}}$, Zhao Yanxiu \\ Hazardous Chemical Substance Equipment Division, China Special Equipment Inspection and \\ Research Institute, Beijing, P. R. China \\ ae-mail: fangzhou@csei.org.cn, be-mail: xingshu@csei.org.cn, ${ }^{\mathrm{c}} \mathrm{e}$-mail: \\ chenqi@csei.org.cn, de-mail: shengongtian@csei.org.cn, ee-mail:zhaoyanxiu@csei.org.cn
}

Keywords: Oil Storage Tank, Risk Evaluation, Inspection Strategy, Case

\begin{abstract}
Inspection of storage tanks has been taken less seriously over past years, as not required by laws. Therefore, projects adopting risk evaluation technology of atmospheric-pressure storage tanks are rarely seen. Characterized by large volume and high risks, hazardous chemicals often lead to serious accidents. This paper evaluates risks of 23 atmospheric-pressure storage tanks of 100 thousand $\mathrm{m}^{3}$ of a storage house. Supposing the storage house implemented inspection within 5 years or 10 years, this paper studies risk changes before and after the inspection. It puts forward an inspection strategy to guarantee long term safety of storage tanks according to the risk analysis outcome.
\end{abstract}

\section{Introduction}

In recent years, with China's rapidly growing demand of energy and crude oil demand constantly refreshes record, the large-size crude oil storage tank has been an inevitable trend [1, 2]. Most large storage tanks in China are located along riverside and coastal cities or located at deep-water wharfs. There are more than 20 tank areas or tank groups which are being constructed or being planned in Yangtze drainage area [3, 4]. Chemical safety of this area determines water supply or survival of tens of millions of local residents. Hazardous chemicals of large volume and high risks may lead to explosion, erosion and pollution in case of accidents. Hidden risks, long-lasting hazards, expansive influence, catastrophic consequences of chemicals often cause more serious social panic than other industries. Figure 1 shows an accident of storage tank. The risk assessment of the storage tanks turns periodic inspection into risk-based inspection, which both ensures safe operation and has a great cost savings [5-7]. 23 storage tanks are all floating-roof tanks, whose host materials include SPV490Q, $16 \mathrm{MnR}, \mathrm{Q} 235-\mathrm{B}$, and Q235-A; the containing medium for storage tank are crude oil, and time-to-use starts from August 2006 to April 2007.

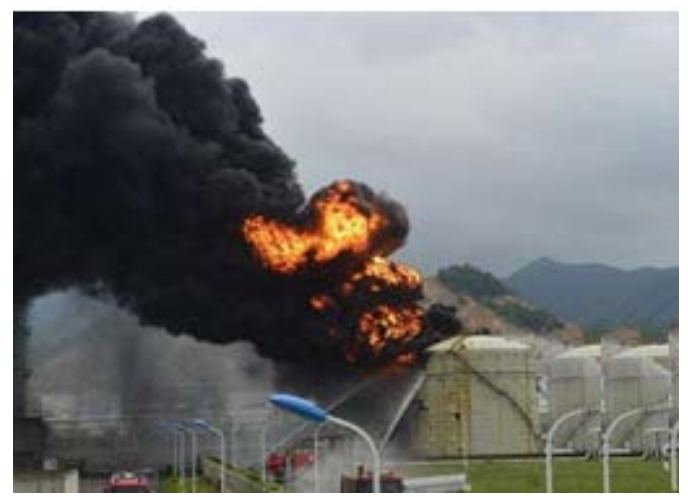

Fig. 1 shows an accident of storage tank 


\section{Analysis about Risk Distribution}

This paper calculates risks of wallboards and baseboards of 23 storage tanks [8-10], so as to predict risk distribution of the current year and in future 5 years or 10 years. Table 1 shows the risks of wallboards and baseboards of 3 tanks as examples.

Table 1 The risks of wallboards and baseboards of 3 tanks as examples

\begin{tabular}{|c|c|c|c|c|c|c|c|c|c|c|}
\hline Tank No. & Unit Name & $\begin{array}{c}2016.9 \\
\text { Damage Level }\end{array}$ & $\begin{array}{c}\text { Present } \\
\text { Consequence } \\
\text { Level }\end{array}$ & $\begin{array}{l}\text { Present Risk } \\
\text { Level }\end{array}$ & $\begin{array}{c}2021.9 \\
\text { Damage Level }\end{array}$ & $\begin{array}{c}\text { Consequence } \\
\text { Level } 5 \text { Years } \\
\text { Later }\end{array}$ & $\begin{array}{l}\text { Risk Level } 5 \\
\text { Years Later }\end{array}$ & $\begin{array}{c}2026.9 \\
\text { Damage Level }\end{array}$ & $\begin{array}{c}\text { Consequence } \\
\text { Level } 10 \text { Years } \\
\text { Later }\end{array}$ & $\begin{array}{l}\text { Risk Level } 10 \\
\text { Years Later }\end{array}$ \\
\hline \multirow{2}{*}{ T-6 } & $\begin{array}{c}\text { Wall } \\
\text { boards }\end{array}$ & 3 & $\mathrm{C}$ & 2 & 3 & $\mathrm{C}$ & 2 & 3 & $\mathrm{C}$ & 2 \\
\hline & $\begin{array}{c}\text { Base } \\
\text { boards }\end{array}$ & 3 & $\mathrm{D}$ & 3 & 3 & $\mathrm{D}$ & 3 & 4 & $\mathrm{D}$ & 3 \\
\hline \multirow{2}{*}{$\mathrm{T}-18$} & $\begin{array}{c}\text { Wall } \\
\text { boards }\end{array}$ & 2 & $\mathrm{C}$ & 2 & 3 & $\mathrm{C}$ & 2 & 3 & $\mathrm{C}$ & 2 \\
\hline & $\begin{array}{c}\text { Base } \\
\text { boards }\end{array}$ & 3 & $\mathrm{D}$ & 3 & 4 & D & 3 & 4 & $\mathrm{D}$ & 3 \\
\hline \multirow{2}{*}{$\mathrm{T}-48$} & $\begin{array}{c}\text { Wall } \\
\text { boards }\end{array}$ & 2 & $\mathrm{C}$ & 2 & 2 & $\mathrm{C}$ & 2 & 2 & $\mathrm{C}$ & 2 \\
\hline & $\begin{array}{c}\text { Base } \\
\text { boards }\end{array}$ & 3 & $\mathrm{D}$ & 3 & 4 & D & 3 & 4 & D & 3 \\
\hline
\end{tabular}

Devices with higher risks mainly concentrate on baseboards and devices with lower risks mainly concentrate on wallboards. Risks of baseboards increase faster than those of wallboards.

\section{Risk Trend after Inspection}

Risk evaluation aims to provide basis for working out an inspection strategy. Risks of storage tanks will experience more changes after inspection. Supposing a storage house implements inspection within 5 years and 10 years, this paper studies risk changes before and after inspection and obtains the outcomes shown in Fig.2 and Fig. 3.

Yellow wedges in the figure indicate risk changes over time without inspection. Blue wedges indicate risk changes over time after inspection. Inspection within 5 years and inspection within 10 years could respectively reduce risks of 23 storage tanks by $27.23 \%$ and $64.09 \%$.

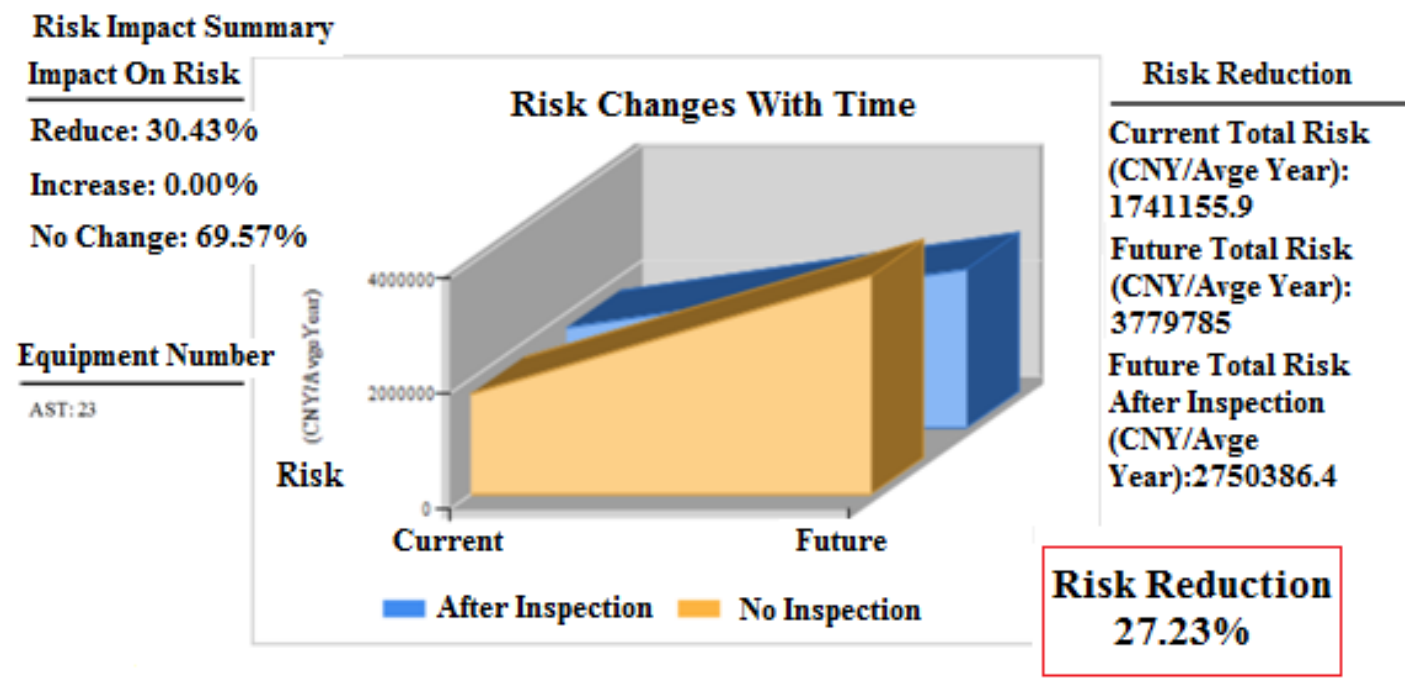

Fig.2 Risk changes before and after inspection within 5 years 


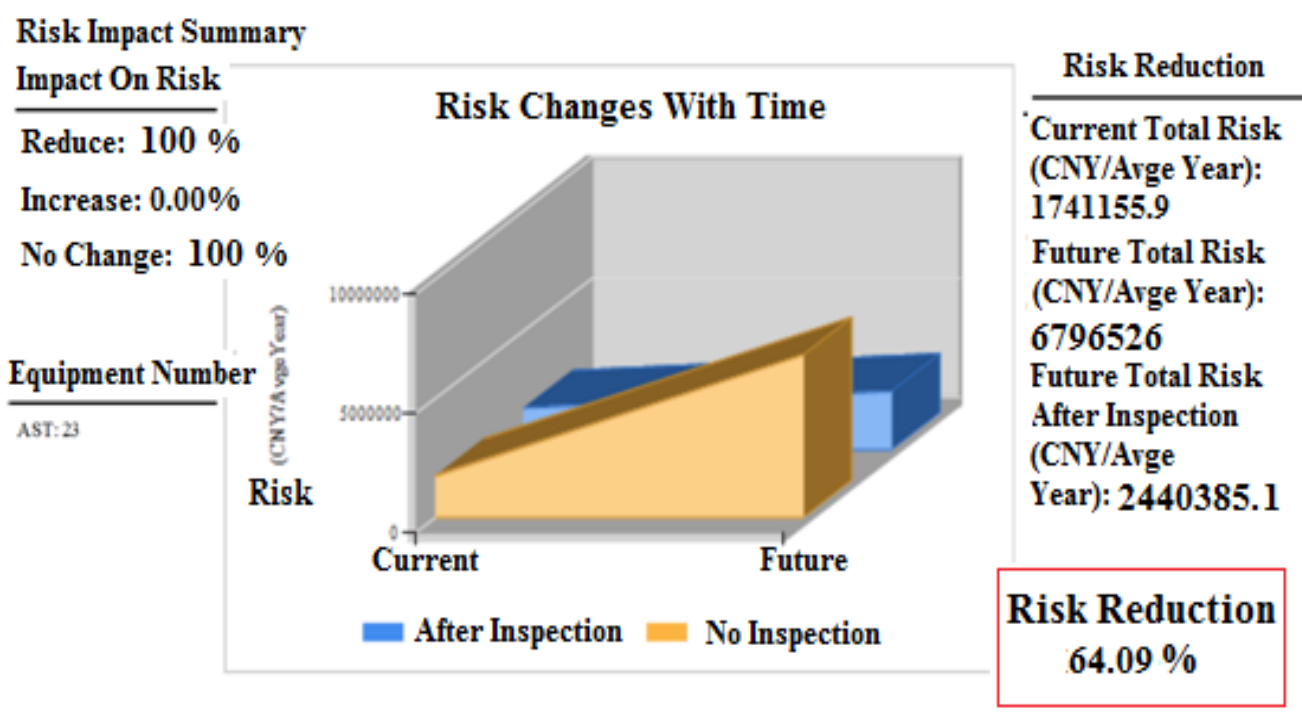

Fig.3 Risk changes before and after inspection within 10 years

\section{Suggestions for Inspection Strategy}

According to risk analysis outcome, baseboards of 23 storage tanks present medium or higher risks and wallboards only present medium risks. Therefore, the time for baseboard damage factor to reach target value shall be taken as reference to determine inspection moments of storage tanks. Inspection moments are suggested in Fig. 4.

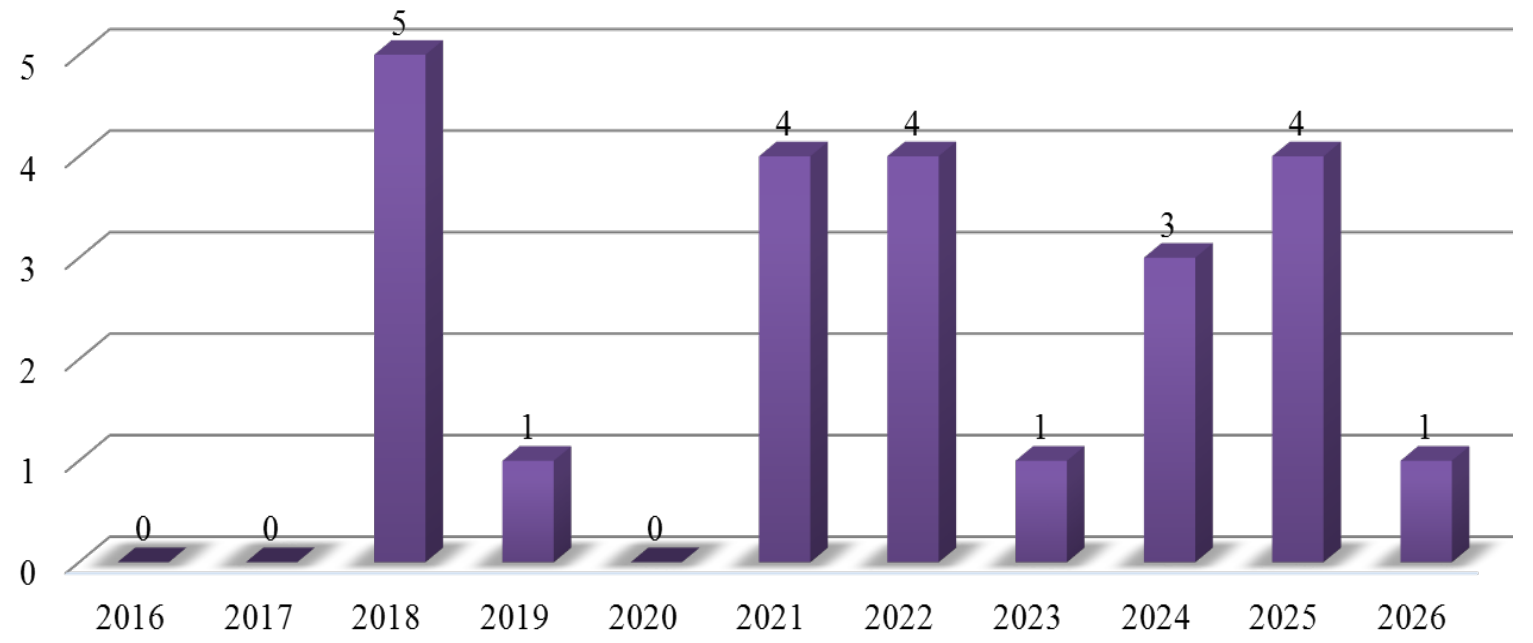

Fig. 4 Inspection moments suggested by baseboard risk

According to hidden invalidation mechanism and risk evaluation outcome of 23 storage tanks, this paper comes up with the inspection strategy in normal condition of the 23 storage tanks. Inspection strategy of 3 storage tanks is shown in Table 2 as examples.

\section{Summary}

This paper evaluates risks of 23 atmospheric-pressure storage tanks of 100 thousand $\mathrm{m}^{3}$ of a storage house. Supposing the storage house implemented inspection within 5 years or 10 years, this paper studies risk changes before and after the inspection. It puts forward an inspection strategy to guarantee long term safety of storage tanks according to the risk analysis outcome. 
Table 2 Inspection strategy of 3 storage tanks as examples

\begin{tabular}{|c|c|c|c|c|}
\hline $\begin{array}{l}\text { Tank } \\
\text { No. }\end{array}$ & $\begin{array}{l}\text { Latest } \\
\text { Inspection } \\
\text { Moment }\end{array}$ & $\begin{array}{c}\text { Suggested } \\
\text { Lowest } \\
\text { Effectiveness } \\
\text { of Inspection }\end{array}$ & Inspection Strategy of Open Tank & Online Inspection Strategy \\
\hline T-06 & 2021-12 & $\begin{array}{c}\text { Low } \\
\text { Effectiveness }\end{array}$ & $\begin{array}{l}\text { Baseboard: } \\
\text { a)ultrasonic thickness measurement on basis } \\
\text { of spot check } \\
\text { Wallboard: } \\
\text { a) macroscopic examination of no more than } \\
50 \% \\
\text { b) fixed ultrasonic thickness measurement of } \\
\text { external part }\end{array}$ & $\begin{array}{l}\text { Baseboard: } \\
\text { a) acoustic emission inspection } \\
\text { Wallboard: } \\
\text { a)macroscopic inspection of } \\
\text { less than } 5 \% \\
\text { f)fixed ultrasonic thickness } \\
\text { measurement of external part }\end{array}$ \\
\hline T-18 & 2019-10 & $\begin{array}{c}\text { Medium } \\
\text { Effectivenes }\end{array}$ & $\begin{array}{l}\text { Baseboard: } \\
\text { a) } 100 \% \text { macroscopic inspection and etch pit } \\
\text { measurement } \\
\text { b) ultrasonic thickness measurement of } \\
\text { suspicious part by } 10 \% \text { of baseboard flux } \\
\text { leakage, high frequency guided waves, or } \\
\text { ultrasonic C scanning system } \\
\text { c) ultrasonic reexamination of baseboards } \\
\text { with abnormal flux leakage signals } \\
\text { d) implement vacuum leakage test in case of } \\
\text { the etch depth } \geq 1 / 2 \text { of the plate depth } \\
\text { Wallboard: } \\
\text { a) macroscopic examination of no less than } \\
20 \% \\
\text { b) Implement ultrasonic thickness } \\
\text { measurement or ultrasonic } C \text { scan at the part } \\
\text { inspected by fixed thickness measurement }\end{array}$ & $\begin{array}{l}\text { Baseboard: } \\
\text { a) acoustic emission inspection } \\
\text { b) implement high frequency } \\
\text { guided wave inspection at the } \\
\text { margin plate with abnormal } \\
\text { signals of acoustic emission } \\
\text { inspection (implement the } \\
\text { inspection at outer part of the } \\
\text { margin plate) } \\
\text { Wallboard: } \\
\text { a) macroscopic examination of } \\
\text { no less than } 20 \% \\
\text { b) Implement ultrasonic } \\
\text { thickness measurement or } \\
\text { ultrasonic C scan at the part } \\
\text { inspected by fixed thickness } \\
\text { measurement }\end{array}$ \\
\hline T-48 & 2018-11 & $\begin{array}{l}\text { Medium } \\
\text { Effectivenes }\end{array}$ & $\begin{array}{l}\text { Baseboard: } \\
\text { a) } 100 \% \text { macroscopic inspection and etch pit } \\
\text { measurement } \\
\text { b) ultrasonic thickness measurement of } \\
\text { suspicious part by } 10 \% \text { of baseboard flux } \\
\text { leakage, high frequency guided waves, or } \\
\text { ultrasonic C scanning system } \\
\text { c) ultrasonic reexamination of baseboards } \\
\text { with abnormal flux leakage signals } \\
\text { d) implement vacuum leakage test in case of } \\
\text { the etch depth } \geq 1 / 2 \text { of the plate depth } \\
\text { Wallboard: } \\
\text { a) macroscopic examination of no less than } \\
20 \% \\
\text { b) Implement ultrasonic thickness } \\
\text { measurement or ultrasonic } C \text { scan at the part } \\
\text { inspected by fixed thickness measurement }\end{array}$ & $\begin{array}{l}\text { Baseboard: } \\
\text { a) acoustic emission inspection } \\
\text { b) implement high frequency } \\
\text { guided wave inspection at the } \\
\text { margin plate with abnormal } \\
\text { signals of acoustic emission } \\
\text { inspection (implement the } \\
\text { inspection at outer part of the } \\
\text { margin plate) } \\
\text { Wallboard: } \\
\text { a) macroscopic examination of } \\
\text { no less than } 20 \% \\
\text { b) Implement ultrasonic } \\
\text { thickness measurement or } \\
\text { ultrasonic C scan at the part } \\
\text { inspected by fixed thickness } \\
\text { measurement }\end{array}$ \\
\hline
\end{tabular}

\section{Acknowledgment}

This work was supported in part by the financial from National key scientific instrument and equipment development project (Project No.2012YQ090175), the Science and technology projects of General administration of quality supervision, inspection and quarantine of P. R. China (AQSIQ), (Project No.2013QK018), (Project No.2014QK244), Quality inspection of public welfare scientific research Foundation of China (Project No.201310156), and PhDs Foundation (Project No.2016 nei21). 


\section{References}

[1] Fang Z, Jia G D, Liu D Y. Study On Carburizing Inspection Of Cracking Furnace Tube Using Acoustic Emission Technique [C]. Proceedings of the ASME 2014 Pressure Vessels \& Piping Conference, 2014.

[2] Fang Z, Chen Z. P, Wang L. Study on high-temperature naphthenic acid corrosion of type 304 and type 316L stainless steel and their welded joints[C]. ASME Meeting. 5 (2009) 351-357.

[3] Fang Z, Hu W.W, Liu D.Y. Study on Metallography Test of the Steel SPV490 for Atmospheric Storage Tank after Fire[C]. Proceedings of the ASME 2016 Pressure Vessels \& Piping Conference. 2016.

[4] Fang Z, Chen Z. P, Jia G D. Dynamic Experimental Investigation on the Self-Vibration Characteristics of Liquid Storage Tanks Under Seismic Excitations[C]. 2013 ASME Pressure Vessels and Piping Division Conference, July 14-18, Paris, France. ASME Pressure Vessels Piping, 2013.

[5] Fang Z, Chen Z P, Yan S J, et al. Ф $2800 \mathrm{~mm}$ nonmetal storage tank is a large earthquake simulation test of anchorage in Chinese. [J]. Pressure Vessels. 2012, 29(6): 1-8.

[6] Fang Z, Chen Z. P. Effect of Weld on Axial Buckling of Cylindrical Shells. Advanced Materials Research, 2010, 223(4): 139-141, 171-175.

[7] Li G. H, Chen H.Y, Fang Z. Integrity Management of Large Size Atmospheric Storage Tank. 2014 ASME Pressure Vessels and Piping Division Conference, July 20-24, 2014, Anaheim, California, USA. ASME Pressure Vessels Piping, 2014.

[8] American Petroleum Institute. API RP580 Risk based inspection[S]. 2009.

[9] American Petroleum Institute. API 581 Risk based inspection[S]. 2008.

[10]American Petroleum Institute. API 653 Tank Inspection, Repair, Alteration, and Reconstruction [S]. 2009. 